\title{
In the Shadows: Exploring THE Notion OF "COMMUNITY" FOR TEMPORARY FOREIGN WORKERS IN A BOOMTOWN
}

\author{
JASON FOSTER \\ Alison TAYLOR
}

\begin{abstract}
The rapid expansion of the oil sands in northern Alberta in the early 21 st century led to the use of significant numbers of temporary foreign workers. These foreign workers became a part of the region's so-called "shadow population." This paper examines how the presence of foreign workers affects conceptions of community and social cohesion through the experiences of foreign workers employed in oil sands construction. The study finds foreign workers are excluded from the life of the community due to their differential exclusion, vulnerable and precarious connection to the labour market, experiences of discrimination, and conflicted transnational community identities. The paper discusses the shortcomings of community and social cohesion approaches in addressing temporary foreign workers and considers the policy limitations of a widespread temporary foreign worker program.
\end{abstract}

Keywords: migrant workers; social cohesion; multiethnic community, social exclusion

Résumé. Le développement rapide de l'exploitation des sables bitumeux dans le nord de l'Alberta au début du XXIème siècle a conduit à la croissance significative du nombre de travailleurs migrants temporaires. Ces travailleurs temporaires sont devenus une partie de ce que l'on appelle dans la région la "population de l'ombre". Cet article étudie la façon dont la présence de travailleurs étrangers a une incidence sur les notions de communauté et de cohésion sociale, à travers l'étude des expériences vécues par les travailleurs migrants employés dans les exploitations de sables bitumeux. Cette étude révèle que les travailleurs étrangers sont exclus de la vie de la communauté du fait de leur exclusion différenciée: leur situation de précarité et de vulnérabilité sur le marché du travail, la discrimination qu'ils ont subie, et leur sentiment conflictuel d'appartenance à une communauté multiethnique. L'article examine les lacunes des approches basées sur les notions de communauté ou de cohésion sociale dans la réponse à l'enjeu des travailleurs temporaires, et prend en compte les limites d'une politique d'embauche massive de travailleurs temporaires.

Mots clés : travailleurs migrants, cohésion sociale, communauté multiethnique, exclusion sociale 


\section{INTRODUCTION}

The rapid expansion of the oil sands in northern Alberta in the early 2000s set into motion a series of economic and social dynamics with significant consequences for the province, and in particular, for the Regional Municipality of Wood Buffalo (RMWB), which incorporates Fort McMurray and the surrounding oil sands projects. The RMWB became one of the fastest growing municipalities in Canada due to the influx of workers to build oil sands extraction facilities north of Fort McMurray. These construction projects are of such a magnitude and size, costing in the billions of dollars and employing thousands of workers during construction phases, that they can be termed "mega-projects" (Slootman 2007). Multiple projects are underway simultaneously, placing pressure on supply of skilled construction labour, and leading construction employers to import labour from other parts of Canada and, for the first time, to use temporary foreign workers. Between 2006-2010, over 6,100 foreign workers arrived in Alberta to work in oil sands construction, most ending up in the RMWB (Cummins 2011). The foreign workers became part of the region's "shadow population," which refers to individuals who are not officially recognized through enumeration as residents, and yet who spend time in a region (Haan 2010). In the RMWB, the shadow population was sizable; in 2007 it was estimated at $26 \%$ of the population (four-fifths of whom lived in work camps) (Nichols Applied Management 2007).

Unanticipated by the mega-project planners was the significant stress that would be placed upon the RMWB's physical and social infrastructure (Oil Sands Ministerial Strategy Committee 2006). Some of this stress related to integrating tens of thousands of workers into the life of the RMWB. For any temporarily located worker, the challenges of making one's way in a new location - accessing amenities, seeking cultural and recreational activities, making social connections — can be significant. For temporary foreign workers, these ordinary challenges are compounded by cultural and, often, language differences (de Guerre 2009). In addition, structural elements of their precarious residency due to government rules surrounding temporary foreign workers add an additional barrier to integration (explained below). The experiences of temporary foreign workers in the RMWB raise questions about traditional notions of how one builds community and social cohesion. Although it could be argued that the migrant worker program has no intention of trying to integrate these workers as a permanent part of Canadian society, our interviews suggest that most want to stay and their employers usually want to retain them. Further, their presence affects the broader community. 
This paper therefore asks how foreign workers' marginalized economic and social position affects their inclusion within a geographically defined community, and what consequences there are for that community and for community as a kind of belonging. In particular, three barriers to community inclusion characterize foreign workers' experiences in northern Alberta. First, their vulnerable and restricted residency status produces a series of economic and social insecurities that both preempt participation in the receiving community and build estrangement from source communities. Second, the workers possess contradictory community identities, which mediate status-based exclusion. Third, their physical location in work camps enhances separation from life in the RMWB. This paper explores some of the ways in which temporary foreign worker policy and practice contradict key assumptions of policy makers and scholars about what makes a cohesive community (cf. Wetherell 2007).

\section{The Precariousness of Temporary Foreign Workers}

Temporary foreign workers possess a unique legal status in Canada that distinguishes them from other mobile workers who come to the RMWB for oil sands jobs and is relevant to their experiences in Canada described below. Their presence in Canada is governed by the Temporary Foreign Worker Program (TFWP), a federal program jointly run by Citizenship and Immigration Canada (CIC) and Human Resources and Skills Development Canada (HRSDC). A full explication of the TFWP is beyond the scope of this paper (for overviews, see Nakache and Kinoshita 2010; Foster 2012); however, a number of elements of the program's purpose and design are relevant here. The TFWP is Canada's version of a migrant worker program (Martin 2003), designed to create a class of temporary residents tied directly to nonpermanent employment. The expressed intent of the program is to address short term labour shortages in specific occupations and industries (Fudge and McPhail 2009). However, as Sharma (2007:175) argues, the program is highly racialized as it "legalized the re-subordination of many nonwhites entering the country by re-categorizing them as temporary and permanently foreign workers." It also marked a shift in Canadian immigration policy away from permanent settlement (Hennebry 2010).

The TFWP has a variety of streams, including live-in caregivers, agricultural workers, and unskilled workers. The trades workers under consideration in this study are considered skilled workers. The TFWP is employer driven, in that the employer initiates the process by requesting 
permission to hire foreign workers. During the period of this study, the program required that the employer guarantee full-time employment, abide by all employment laws, and pay wages equivalent to the market rate for permanent residents. Work permits granted to foreign workers under the TFWP are for a specified period, usually one or two years, and further specify the employer, occupation, and location of work.

Foreign workers in the compulsory construction trades are given six months to pass their trade's national certification exam, commonly referred to as the Red Seal exam. They are permitted to work in their trade as they prepare to write the exam. They are provided two opportunities to pass (a grade of $70 \%$ or higher achieves the Red Seal while a grade of 68 or $69 \%$ achieves the Alberta trade certification). If they do not meet one of these standards, they are required to return to their home country. As will be seen below, this requirement produced significant stress for the participants in the study.

The TFWP's rules construct a precarious legal status that has a number of consequences for foreign workers. First, their physical presence in Canada is dependent upon the employer and maintaining an employment relationship. Their restricted ability to switch employment or location also places them in an unusually vulnerable position vis-à-vis their employer (Wong 1984; Martin 2003; Fudge 2011; Abella 2006). Their enhanced vulnerability makes it more difficult for them to access their statutory employment rights (Nakache and Kinoshita 2010), and reports indicate that foreign workers are more likely to experience violations of those rights (Fudge 2011).

Furthermore, foreign workers are not allowed to access settlement services available to permanent immigrants, which, combined with language and cultural barriers, leads to a high degree of social isolation and estrangement from the community and greater dependence on employerprovided orientation, information, and services (Pastor and Alva 2004; Anderson 2010). Access to permanent residency streams are limited for skilled foreign workers. In the two avenues available, the skilled worker program and the provincial nominee program (PNP), applications greatly exceed the number of available nominations. Consequently, only a small percentage of foreign workers successfully navigate the process for permanent residency (Nakache and Kinoshita 2010).

The precariousness of foreign workers' status in Canada plays a direct role in their capacity and willingness to engage with the community in which they are residing. To a large degree, it defines their relationship to others, and defines them as "other," as discussed below. 


\section{Foreign Workers, Precariousness and Community}

The concept of community has long been problematic in sociology. By the 1950s dozens of definitions were in use by social theorists (Hillery 1955) and today it continues to be a contested term.

While there is a formal consensus that to talk about community is to talk in a commendatory way, there is no such consensus about what precisely is being commended in terms of empirically detectable features of social life. (Plant 1978:82)

However, in the public imagination, community is a powerful symbol.

Traditionally, the idea of community was anchored in a geographic sense of space and the commonalities that arise from shared space (Plant 1978); however, the concept must remain elastic enough to address nonphysical communities made up of people with similar values or interests, or who share a commonality across a virtual plane (Brint 2001). At the core of the complexity is a sense that community is about both collective identity and shared interaction. As Amit (2002:8) argues:

If communities must be imagined, then by the same token, what is imagined can only be truly felt and claimed by its potential members if they are able to realize it socially, in their relations and familiarity with some, if not every other constituent. To treat the idea and actualization of community as if these are in essence independent elements is to leave us and our analyses with only one hand clapping.

Temporary foreign workers' precarious legal status and divided community "location" - as transnationals who are members of a home community yet reside in another - make it almost impossible for them to realize the idea of community as understood and lived in the geographical area in which they work. They are limited in their ability to actualize community with those located around them (co-workers, Fort McMurray residents) because of their inability to participate in social and economic relations. The foreign workers who participated in our study resided in work camps outside the Fort McMurray townsite, further challenging common understandings of community.

Traditional conceptions of community are also problematic when applied to foreign workers (and other groups) due to their tendency to emphasize unity and uniformity among community members (Putnam 2007). If this focus marginalizes and silences certain groups and viewpoints (Young 1986), it further entrenches racialized, gendered, and class-oriented social patterns of disadvantage (O'Brien 2008). Foreign workers are, indeed, one of those marginalized groups. 
Recent efforts to resurrect strong communities amid increasing diversity have turned to Robert Putnam's $(1993 ; 2000)$ work on social capital and increased associations to build cohesive groups. The so-called "community cohesion" movement is seen as a way to bridge differences between individuals to construct a common sense of belonging (Cantle 2005; Wetherell et al. 2007). The unit of analysis is the neighbourhood, where people physically share space and interact. In this theory, community retains its physicality yet attempts to transcend diverse identities.

However, the idea of community cohesion does not escape the core problem of overemphasis on integration and assimilation.

[T] he contemporary community cohesion agenda has overblown differences of ethnicity, is unwarranted in maintaining that the problem is with minority ethnic communities and is wrong in many of the conclusions drawn to legitimize the specifics of the policy response. (Robinson 2005:1412; emphasis in original)

Ethnic minorities are usually held to have "the wrong kind of "community,' the wrong kinds of values and the wrong kinds of connections" (Alexander 2007:121). Critics argue that cohesion advocates ignore important economic and structural barriers to full participation in community by focusing on attitudes and social integration rather than material circumstance (McGhee 2003), and that they downplay the role of the state in interfering with cohesion through policies that entrench existing economic inequalities (Worley 2005; Wetherell 2007).

In an attempt to move the concept of cohesion beyond neighbourhood boundaries, some theorists have explored the broader concept of social cohesion. Analysts of social cohesion consider how societies "are bound together through the action of specific attitudes, behaviours, rules and institutions which rely on consensus rather than pure coercion" (Green et al. 2009:19). Here, the geographic boundaries of community expand to the local and national level, but no further; thus, "diasporic communities are significantly absent" from the analysis (Alexander 2007:119).

As in the community cohesion thesis, emphasis is often on the barriers to building social cohesion. In Canada, these are usually identified as immigration and cultural diversity (Toye 2007) as well as underdevelopment of Aboriginal nations and uneven regional development (Ferguson et al. 2009). Consequently, social cohesion may fail to recognize how cohesion can exacerbate and intensify existing social and material inequalities through reinforcing group boundaries, placing many racialized and gendered individuals on the outside (Leach and Yates 2008). For example, Gibbs (2008) found that increasing social cohesion among "Canadian" workers can lead to decreased solidarity with Mexican work- 
ers both in and outside Canada, as social cohesion intensifies definitions of Mexicans as "other."

Both community and social cohesion perspectives aim to strengthen ties between people living in community defined in a physical sense, and thus purport to offer solutions for the vexing problem of exclusion of marginalized groups (Reitz and Banerjee 2007). However, with their emphasis on integration and shared values, there are questions as to how well they can achieve this goal. The questions are intensified once temporary foreign workers enter the equation. How well do efforts at cohesion address the precarious situation of foreign workers residing in a geographic community, especially a booming resource region with high rates of mobility?

\section{“Transnationalism," Citizenship, and Foreign Workers}

The concept of community/social cohesion becomes more problematic when applied to temporary foreign workers because of the requirement that such workers develop or maintain a transnational community identity (as temporary residents) and their exclusion from many aspects of Canadian society (as noncitizens). The resource extraction sector, which is a key driver of the Alberta economy, has been a common source of economically related migration (Abella 1995). One of the consequences of increased migration, including the greater use of temporary foreign workers (Martin 2003), is the rise of what some writers refer to as transnational identity, which cannot be understood using traditional ideas of community (cf. Vertovec 2009). "Increasing numbers of international migrants do not simply move from one society to another, but maintain recurring and significant links in two or more places" (Castles and Miller 2009:47), including, in our case study, wives and children and other familial networks. This transnational identity is both contradictory and conflicted (Castles 2002), in that its dual nature is not easily resolved. Temporary foreign workers, as a subset of migrants, face a unique set of pressures as their tenuous and precarious residency in the receiving country make actualizing a sense of community in their new (temporary) home more difficult and yet they retain the challenge of maintaining bonds with their home community.

Workers' conflicted identity and impermanent location weakens their connection to geographic community (Vergunst 2009). Compounding this dynamic, the precarious attachment of temporary foreign workers to local labour markets results in a "lack of social attachment and a preparedness to forego social pleasures" (Anderson 2010:305). In other 
words, foreign workers can be demotivated to become involved in activities in the community in which they reside because they are centrally focused on work, which enhances their estrangement. The fast-paced and work-focused resource economy of Fort McMurray illuminates and exacerbates this facet of exclusion.

Simultaneously, temporary foreign workers' contingent status in the host country raises barriers to their attachment to the new community. Temporary migrant workers' lack of full citizenship status within the host country has implications for community inclusion. Castles (2000; 2002) has described the situation of foreign workers as "differential exclusion," where they are incorporated into certain areas of society (e.g., the labour market) but denied access to others (e.g., welfare systems, citizenship, political participation) through legal mechanisms or informal practices. In most parts of Canada, including Alberta, temporary foreign workers possess limited residency rights, restricted labour mobility rights, and problematic access to basic employment rights (Fudge and McPhail 2009). These restrictions constitute a form of "institutionalized uncertainty" (Anderson 2010:311) and lead to a position of differential exclusion. The concept of differential exclusion is helpful for our purposes as it directly addresses the processes that lead to certain groups being marginalized from sociocultural community life and accentuates some of the problems associated with the cohesion debate.

The issue of community inclusion becomes particularly relevant in the oil sands of Alberta. Not only are the workplaces physically isolated from any urban centre (the consequences of which are discussed further below), but the economic model adopted by companies in the region exacerbates barriers to community involvement. Employers in the sector have adopted a just-in-time approach to labour supply, which constructs a contingent and precarious connection with the workplace, the employer, and the community. Interprovincial migrant workers have reported experiencing stress at navigating the partial existence in two locations (Ferguson 2011). These stresses extend to foreign migrant workers, and thus make the RMWB an important area for study.

\section{Method and Participant Overview}

As part of a study on the effects of the TFW Program on oil sands construction, we interviewed 27 people involved with the foreign worker program in the industry, including a total of 11 foreign workers. The remaining interviews included 5 employers/recruiters, 3 union officials, 6 government representatives and 2 nonprofit agencies. The semistruc- 
tured interviews were conducted in the fall/winter of 2010-11 and were 45-90 minutes in length. A preinterview survey was also completed by the workers to collect demographic and employment-related information. Translation services were offered; however, the workers' spoken English was sufficient to forego translation.

All of the interviewed workers were men and came from two countries: nine from the Philippines and two from India. These two countries together represented the largest portion of foreign workers recruited to Alberta. Among the workers were two electricians, seven pipefitters, one welder, and one ironworker. Nine had previous experience working in international oil fields, most commonly in the Middle East, Russia, and Northern Africa. A majority had previously trained in other occupations, including civil and electrical engineering, and industrial technology. One previously ran his own business. All workers had a spouse and children back home and were submitting remittances.

The timelines for their arrival varied. Most arrived during the height of the boom in 2006 and 2007. Two arrived following the 2008 crisis (although they had begun the application process before the crash) and one first arrived in 2003. All reported paying recruiters' fees in their home country for handling their application. Fees ranged from $\$ 2,000-\$ 9,000$ and were often financed in a way that significantly increased the amount owed, creating a significant burden. Since their arrival, workers' experiences of employment in Alberta had been sporadic. Most had worked for multiple employers since arriving in Canada, with some reporting as many as four or five. Some arrived to find their job had disappeared. Others worked for a few weeks or a couple of months and were laid off. A common experience was prolonged periods of unemployment alternating with periods of intense work at high pay. Two were able to collect Employment Insurance benefits, but most relied on savings, frugality, and informal support mechanisms such as sharing housing between multiple foreign workers. Four were required to return to their home country in between jobs.

The pattern of insecure employment leading to high rates of mobility tends to be common for all construction workers in Alberta. However, TFWs are usually the first laid off from a worksite and the last to be rehired. This means the foreign workers experienced an even more precarious and volatile employment pattern than permanent residents. In addition, the restrictive nature of their work permit makes it more difficult to find alternative employment with another contractor and impossible to seek work in other occupations or regions, further marginalizing them in the labour market. 
Seven of the ten workers who responded to a question on our preinterview survey reported experiencing some degree of discrimination, usually due to their race or ethnicity. One was not sure and two others did not report discrimination. Our interviews revealed incidents in the workplace, in the camps, and in the broader community. However, no worker reported taking any significant action to report or curtail it. This muted response should not be construed as passivity and is more reflective of their broader perspective and vulnerability, discussed further below.

Most of the interviewed TFWs expressed an interest in long term or permanent residency in Canada, despite the time limits on their work permit. None intended to only stay for a year or two. They hoped, at minimum, to remain for a few years, for example: "Maybe after 10 years I have enough money so maybe I'll go back to the Philippines and start a business" (19, TFW). Most came with the desire to remain permanently and bring their families, while others developed an intention to stay while here: "First I [thought] I'll just work here and go back to India. Now I am thinking I will bring my family here permanently" (12, TFW). Thus, there is a clear disconnect between the hopes of the workers and the regulations of the TFWP.

At the time of interviewing, only two workers had successfully achieved permanent residency, and six were in process. All utilized the provincial nominee program in Alberta. This number is unlikely to reflect the experiences of the foreign worker population in the oil sands more generally since interviews were conducted after the 2008 crash and most of the 6,100 TFWs had returned home. The interviewed workers thus represent the minority who had successfully navigated the difficult and complex process toward permanent residency.

It is important to note that a number of the workers interviewed were experienced migrant workers: "[W]e always work in other countries. That's why we are used to being away from our family. We call them and send them money" (18, TFW). These workers shared a number of common features, including previous experience, often extensive, as migrant workers in oil-related construction in other countries. This has four significant dimensions. First, their work history in international oil fields no doubt contributed to their selection by Canadian contractors. Second, these men are used to long stretches away from home and accustomed to working long hours in unfamiliar geographic and social locations. Third, many of the men made the decision to switch to construction trades as a way to achieve greater economic security, despite the downside of being separated from family and friends. Fourth, Canada was only one of several options open to them, and often was not their first choice. The decision to come to Canada was usually based on instrumental reasons, 
including money, safety, and Canada's reputation for good working conditions. These men are thus part of a growing class of workers choosing to enter a transnational labour market. Their acceptance of suboptimal circumstances and unwillingness to challenge unjust situations is a feature of both their vulnerability and their perspectives as transnational workers, as we see in the discussion that follows.

\section{Exclusionary Positions}

During their time in Alberta, the foreign workers interviewed for this study expressed distance from the community around them. There appear to be three reasons for this sense of exclusion. First, their precarious work and residency status, caused by their restrictive work permits and the requirement to pass the Red Seal exam, and intensified by their experiences of discrimination, constructed a position of differential exclusion as described above. Second, their transnational identification, which was enforced by their temporary status, complicated their relationship to the host community. Third, living in work camps at oil industrial sites created a physical segregation from the Fort McMurray townsite. While physical segregation and its marginalizing impacts might be true for all members of the large and diverse shadow population, in particular those living in camps, only foreign workers experience a combination of all three factors. Their heightened precariousness leads to an intensification of exclusionary processes. We discuss the three factors in more detail below.

\section{Differential Exclusion}

If you don't have permanent residence you're always afraid [of] everybody, afraid [of] your boss that you'll be sent back home. You don't have peace of mind. That's a problem when you [are a] foreign worker, you're always thinking before you go to sleep what will happen tomorrow, I might be sent back home. You don't know. (15, TFW)

The interviewed workers expressed anxiety about the uncertainty of their residency and were acutely aware of their precarious legal status in Canada. The work permit symbolized their tenuous claim on belonging in Canada, as noted by one Filipino worker: "To get our family and to have security in our job, that is the main thing. Once we are residents here you don't need working permit" $(18$, TFW).

All of the workers interviewed articulated unease about their contingent stay in Canada. Present in their tone was a worry of doing something 
wrong that might lead to deportation. Their concern about working hard to present an appropriate face was evident in interviews, where it seemed apparent that workers were withholding negative impressions and experiences. In one interview, it became apparent that despite interviewer attempts to clearly explain the research verbally and in writing, the participant (who was unemployed at the time) thought we represented an employment or government agency that could help him find work. The participants also presented an active desire to perform well at work. This is confirmed from interviews with employers, whose perceptions of the workers were that they were productive, compliant, and well-mannered.

[With temporary foreign workers] we're dealing with a dedicated workforce. We're also dealing with a workforce for supervisors that end up being malleable.... [T]hey're very appreciative and prepared to work very hard to sustain their employment. ( 8 , employer)

However, a few workers spoke of employers using the temporary nature of their status as a threat to work longer hours or do unpalatable work. One worker relayed a story of a manager making repeated demands of weekend overtime, including on Sunday:

I said, "No, because Sunday I can't go to work because I have to go to church." He knew that already long time ago but he insisted. "You have to work Saturday and Sunday." I said, "No, not now."... So he said, "You know what, I will [get] a boat and I will send you home." (16, TFW)

The turbulent work patterns experienced by the foreign workers compounded the impact of differential exclusion. The reality that they were to be the last hired and first fired was never far from their minds. This awareness mentally destabilized the workers and led many of them to adopt short-term goals, rather than consider long-term plans such as buying a house or building lasting relationships. It also made others reconsider their status. Ironically, a worker who initially did not plan to remain in Canada soon realized that the most likely way to achieve stable work and a steady income was to gain permanent status:

When things happened to me, when I [was] laid off and I waited for a year, I [changed] my thinking that it's better for me to apply for PR [permanent residency]. (19, TFW)

The requirement that the foreign workers pass the Red Seal exam within six months affected their integration and the possibility of realizing community in three ways. First, our interviews revealed that foreign workers experienced a high failure rate on the exam. No official figures are available from the government, as our requests for data about 
TFW pass rates were declined, but both employers and foreign workers confirmed that fewer than half pass the exam, and reported that in some sittings only $10-20 \%$ passed. To place this in context, only about half of Canadian workers in Red Seal trades achieve the Red Seal and few apprentices complete their training on time (Gunderson 2009; Prasil 2005). Yet in the case of foreign workers, after six months of satisfactorily meeting job requirements while working long hours in a camp those who cannot pass the written certification exam are usually sent home. That such stringent exam requirements and tight timelines are applied only to foreign workers is a clear example of institutional differentiation and exclusion.

Second, the looming deadline of six months weighed on the workers' minds. Many reported seeing co-workers who failed the exam sent home and were aware that if they did not pass, they, too, would lose their residency.

At five months, we take the first exam. Then second time was six months. I failed it the first time. For the second time they said, if you don't pass for the second time you go back to the Philippines. (14, TFW)

All of the interviewed workers indicated that they found the exam hard, due to differences in technical language, and half failed the first attempt. The added threat of being sent home was cause for anxiety.

Third, employers recruiting large numbers of TFWs attempted to assist them in their preparations for the exam by offering classes after work and on weekends. While beneficial, the classes and the time spent studying for the exam detracted from the already limited time available to socialize and relax. "Three months before I challenged the written test I read those books before I go to sleep, before I go to work, every day" $(16, T F W)$. Certification requirements thus further ensured that a work identity was the only identity permitted.

Discrimination also played a role. Specific incidents were reported, both in the community (one worker received a flurry of racial epithets from a driver stopped at a crosswalk) and in the workplace. One reported that desirable overtime went to "white guys." Another identified shift segregation as a problem.

We were assigned on nightshift because no one likes to work at night.... Canadians don't like to work nightshift. So we have no choice, we have to work in the night. (15, TFW)

Night shifts are seen as less desirable and make it more difficult to engage in community activities such as attending events or running errands, which tend to assume a traditional workday. It is noted that the workers' 
response to such incidents was muted. This reflects two characteristics of their experience. First, their vulnerable status, both at work and in the community, makes reporting a risky activity. Second, the workers were willing to put up with discrimination in the short term to achieve the longer term goal of stable work and permanent residency. Regardless, the outcome is workers' loss of voice.

\section{Divided Community Identity}

It's really hard [to leave my family] the first time because we have this bond. It's our culture, bonded family. For the first time it's really hard but I'm figuring out that [my] kids are growing up and they want to go to university and I can't let them go. That's really hard for me, big responsibility. (13, TFW)

Our TFW participants displayed a conflicted and contradictory identity that is reportedly common among foreign workers (Castles 2002). While almost all expressed a desire to remain in Canada and were motivated to learn how Canada works and to acclimatize themselves, their primary commitment and connection was to family and community back home. The choice of Canada was often based upon diasporic social connections here: "I really want to work in Canada because lots of friends of mine from my town came here" ( $9, \mathrm{TFW})$. The reason for their presence in Canada was to give their families opportunities they would not normally have:

Actually I don't want to get out from our country but since my kids - [it is] all about family — my kids growing up. The Philippines, I don't want to say this but the Philippines belongs to third world country. [Canada is] a certain opportunity, when I was qualified to work to get in here, I have to grab that opportunity. $(13, \mathrm{TFW})$

These apparently contradictory expressions come together when we consider why they want to remain in Canada. Their reasons are pragmatic. Initial attraction included the relatively high wages offered to foreign workers in Canada:

I'm very lucky because pay here is very good. When I was in Saudi Arabia my salary in a month is equivalent [to] only two days here in Canada. That's why every Filipino, every TFW, who comes here is very lucky. We feel lucky because it's a good opportunity for us. (19, TFW)

Their desire is to reunite with their family and provide them with a better future: 
I was hoping that I will bring here my family and also my kids will settle here. That is the only thing that I want to pursue now. I want also to help my brother and sister and my wife's brother and sister. That is the main thing [why] I want to stay here. (18, TFW)

The conflicted identity shines through in this narrative of coming to a new land to support those from home. Of course, the practical requirement that TFWs leave families at home intensifies this conflict.

A desire to come to a new place to better the future for one's family is a common motivation for immigrants (Winchie and Carment 1989). However, this motivation becomes more contradictory when other factors restrict the capacity of migrants to achieve their goals in the new country. For example, the continuing precarious status of long-term migrant workers reinforces contradictory identity. A number of these workers had spent very little face-to-face time with their families over several years. Uncertainties about long-term residency also perpetuate workers' conflicted positions in "home" and "host" communities. Foreign workers are neither "of here," nor are they wholly "of there."

\section{Physical Dislocation}

[The work camp] it's far from the city.... We worked 12 days work, 2 days off. You have to go out in the camp. You're working hard so you [don't think about relaxing].... For us we don't care. Our mind was focused on how to earn money. We worked 12 days and most people were still asking if they can still work. $(9$, TFW)

The foreign workers were located in the isolated work camps north of Fort McMurray. They worked long shifts and a great deal of overtime. On days off, they stayed in camp or went to Edmonton, the closest large city. When laid off during the economic downturn, most returned to Edmonton, explaining that it was easier to look for work there than in the more restricted economy of the RMWB. One worker who remained in the RMWB while unemployed soon left, discouraged by the lack of job opportunities. Most interviewed workers expressed positive impressions of camp life, in particular, its provision of basic needs and its regular routines. Complaints were limited to what were seen as small things: lack of rice at breakfast or undesirable recreational opportunities. This is partly because their singular focus was work. The provision of food and other basics freed them to work.

No doubt camp life is isolating for all camp workers. However, the experience for foreign workers is heightened due to their lack of previous connection to the RMWB or Edmonton, their conflicted community 
identities, and the significant time required to prepare for the Red Seal exam. Camp workers from Alberta or other parts of Canada are likely more familiar with informal cultural and social norms and thus can more readily take advantage of opportunities, such as going into town during off-hours; they are also more likely, even in Fort McMurray, to find culturally recognizable social activities. In contrast, foreign workers' lack of social resources contributed to their isolation.

Their lack of interaction with community in the RMWB reduced any potential for these new arrivals to perceive the region as their home. None expressed plans to settle in the area if/once they received their permanent status. Instead, Edmonton was the location of choice. "It's better, it's a good place. I think there's a lot of work here. In Fort Mac there's not as much" (19, TFW). Edmonton was seen as having more amenities, better shopping, more opportunity for employment, and a lower cost of living, and probably for these reasons, was seen as the place to live as a family. The RMWB was viewed only as a place to work: "We just want to work there in Fort McMurray and stay here in Edmonton. For the kids I want to stay here than to stay in Fort McMurray" (18, TFW). The RMWB was discounted because the workers were physically and psychologically separated from the community and because of the high cost of living if one does not live in a camp.

\section{Discussion}

Foreign workers in the oil sands are part of a growing class of transnational migrant workers who, through a series of regulatory and social processes, are marginalized within Canadian society and local communities. Their position of differential exclusion, due in large part to their precarious labour market attachment and residency status, combines with conflicted transnational identities, experiences of discrimination, and physical isolation to create a degree of marginalization not experienced by other parts of the "shadow population" in the region. In some respects, foreign workers' marginalization is similar to that experienced by other migrant workers working in the oil sands and living in camps, in particular the physical isolation and lack of official recognition in the community. However, the increased precariousness of foreign workers intensifies and entrenches their marginalization in a manner unique from other workers.

In particular, the rules of the TFWP construct a precarious status for foreign workers that severely restrict the potential for community inclusion. First, the temporary nature of their residency imposes a degree 
of insecurity and fear. Second, restrictive work permits (specifying employer, occupation, and location) curtail mobility rights, dampen labour rights protection, and heighten dependence on the employer. Third, the practice of foreign workers being last hired/first fired contributes to economic precariousness. Finally, provincial rules imposing a higher standard of certification on foreign workers than Canadians (Red Seal exam) increase anxiety (and likelihood) of failure and loss of status. The formal rules institutionalize a position of differential exclusion, one rooted in a significant power differential between employer and worker (cf. Tam 2007). This manifests as exclusion from local community.

In part, this exclusionary position is an intended design of the TFWP (Sharma 2001), to create a class of economic residents with limited recourse to other aspects of society. Part of the effect is informal, the byproduct of having precarious temporary workers residing, but not fully participating, in community. Canadians are encouraged by the structure of the TFWP to commodify foreign workers and see them as valuable to the economy but undesirable as members of the community (Bauder 2006), a phenomenon perhaps intensified by the context of the oil sands mega-project.

Foreign workers' conflicted transnational identity further marginalizes them from community, a pattern reinforced by their structural exclusion and economic precariousness. This is not unexpected, as others have argued that individuals deprived of a secure position in society are more likely to disengage from institutions and social practices (Tam 2007). A vicious circle is created.

One of the consequences of foreign workers' exclusion from community is a further undermining of their economic situation. An important component of labour rights is reliable access to social resources knowledge of processes and procedures, informal support networks, and trust in institutions - which are built through community inclusion. Lacking those resources, foreign workers are likely to fare poorly in the labour market compared to other, more connected, workers.

The consequences of the differential exclusion are not felt just by foreign workers; they affect the political possibilities of community as well. Tam (2007) argues that the "progressive solidarity" needed for a truly cohesive society is threatened by the increased mobility and "insecure identities" associated with economic pressures in a free market culture. A community that hosts a population of foreign workers is likely to be less cohesive. As Tam (2007:18) suggests:

If we do not make democratic decisions together, if we seldom join with others except when it is for a narrow instrumental purpose of getting what we want, and if we spend most of our time thinking about earning money 
for ourselves ... then society is at risk of losing its solidarity, incapable of rallying its members to come together for the common good when they will just be inclined to look after their individual selves or groups.

Writers like Johnson (2007:31) thus argue that

it is in the interest of the host community to bestow the legal and psychological security of citizenship on immigrants to enable them to establish roots, contribute to the local community, invest in social capital and care about integration.

While Johnson here refers to immigrants, the argument applies to foreign workers as well.

In addition to implications for foreign workers and communities, our analysis challenges the conceptions of community cohesion and social cohesion. The conception of community usually adopted within policy discourse is a "solid, bounded set of social relationships, located in one place" (Rogaly and Tayler 2007:72). Similarly, identity is usually seen as simple, neatly bounded, and static as opposed to open, shifting, and multiple (Alexander 2007). A community cohesion agenda thus "creates the idea of minority ethnic communities at the same time as it demands their disappearance, and fixes ethnic identity within these community boundaries while demanding it move outside of them" (Alexander 2007:1245). Meanwhile efforts at increasing social cohesion are likely to entrench existing power dynamics between social groups, intensifying social identification for groups with privilege while further marginalizing others.

The migrant workers interviewed expressed not unitary but conflicting transnational identities. These workers, while physically present, are not allowed to be fully a part of the community. Community cohesion policies have no mechanism for integrating such excluded individuals. Social cohesion discourse is "out of step" with policies that overtly exclude groups of individuals through multitiered rights. The state is a central actor, both as the institutional creator of differential exclusion and as a willing accomplice in the marginalization of the migrant workforce. The discourse of cohesion fails to acknowledge the part played by the state in fostering cohesion-threatening differential exclusion, as well as the economic and social inequalities that arise due to this exclusion inequalities that lie at the heart of foreign workers' experiences.

\section{Conclusion}

Questions about the place of temporary foreign workers in communities will grow as Canada's TFWP becomes entrenched in the labour market. 
And those questions will be no more pressing than in RMWB, which, as the epicentre of oil sands development, will likely rely upon migrant labour for some time. Migrant worker programs become larger and last longer than anticipated (Ruhs 2002; Martin 2003) as employers develop a dependency on the ongoing flow of foreign workers (Anderson and Ruhs 2010), creating the potential of a permanent, rotating underclass of foreign workers (Foster 2012; Martin 2010). Evidence of this entrenchment can be seen in 2012 with a series of policy changes that ease employers' burdens in applying for TFWs, allowing for faster processing and lower wages for TFWs (Human Resources and Skills Development Canada [HRSDC] 2012). Another recent change, applying only to Alberta and affecting oil sands construction specifically, essentially "assumes" a labour shortage in oil sands construction, and is a symbol of the perceived permanence of labour need in the sector (Citizenship and Immigration Canada 2012).

One question that arises out of considering the long-term implications of the use of foreign workers is whether, over time, we will see the rise of a foreign worker community "within" the broader community. As temporary foreign workers become a "permanent" feature of Canadian communities, will they find ways to build their own network of social resources to facilitate their life in Canada, especially if prospects for inclusion remain dim?

Finally, our study, while examining only one group of marginalized workers, needs to be understood within a broader framework of exclusion, both in the RMWB and elsewhere. Race, gender, age, culture, and other factors also contribute, in varying degrees, to individuals becoming excluded, partially or wholly, from community. Precarious residency becomes only one important dimension in the making of community.

\section{REFERENCES}

Abella, Manolo. 1995. Asian migrant and contract workers in the Middle East. Pp. 418-423 in Roger Cohen, ed., The Cambridge Survey of World Migration. Cambridge: Cambridge University Press.

2006. Policies and best practices for management of temporary migration, presented at the International Symposium on International Migration and Development, June, Turin.

Alexander, Claire. 2007. Cohesive identities: The distance between meaning and understanding. Pp. 115-125 in Margaret Wetherell, Michelynn Lafleche, and Robert Berkeley, eds., Identity, Ethnic Diversity and Community Cohesion. London;Thousand Oaks, CA: Sage. 
Amit, Vered. 2002. Reconceptualizing community. Pp. 1-20 in Vered Amit, ed., Realizing Community: Concepts, Social Relationships and Sentiments. London; New York: Routledge.

Anderson, Bridget. 2010. Migration, immigration controls and the fashioning of precarious workers. Work, Employment \& Society 24(2):300-317. doi:10.1177/0950017010362141.

Anderson, Bridget and Martin Ruhs. 2010. Migrant workers: Who needs them? A framework for the analysis of staff shortages, immigration and public policy. Pp. 15-52 in Martin Ruhs and Bridget Anderson, eds., Who Needs Migrant Workers? Labour Shortages, Immigration, and Public Policy. New York: Oxford University Press.

Bauder, Harald. 2006. Labor Movement: How Migration Regulates Labor Markets. Oxford; New York: Oxford University Press.

Brint, Steven. 2001. Gemeinschaft revisited: A critique and reconstruction of the community concept. Sociological Theory 19(1):1-23. doi:10.1111/07352751.00125 .

Cantle, Ted. 2005. Community Cohesion: A New Framework for Race and Diversity. Basingstoke, England; New York: Palgrave Macmillan.

Castles, Stephen. 2000. Ethnicity and Globalization: From Migrant Worker to Transnational Citizen. London;Thousand Oaks, CA: Sage Publications. 2002. Migration and community formation under conditions of globalization. International Migration Review 36(4):1143-1168.

Castles, Stephen, and Mark J. Miller. 2009. The Age of Migration: International Population Movements in the Modern World. 4th ed., Rev. \& updated. New York: Guilford Press.

Citizenship and Immigration Canada. 2012. Operational bulletin 279-C: Alberta pilot for occupation specific work permits. http://www.cic.gc.ca/english/ resources/manuals/bulletins/2012/ob279C.asp.

Cummins, Percy. 2011. Oil sands use of temporary foreign workers in Alberta, presented at the Temporary Foreign Workers in the Oil Sands in Alberta: What Have We Learned? April 19, Work and Learning Network, University of Alberta. http://www.wln.ualberta.ca/seminar resources/2011/ CumminsApr19 11.pdf.

Ferguson, Barry, Simon Langlois, and Lance W. Roberts. 2009. Social cohesion in Canada. The Tocqueville Review 30(2):69-101.

Ferguson, Nelson. 2011. From coal pits to tar sands: Labour migration between an Atlantic Canadian region and the Athabasca oil sands. Just Labour 17:106-118.

Foster, Jason. 2012. Making temporary permanent: The silent transformation of the Temporary Foreign Workers Program. Just Labour 19:22-46. 
Fudge, Judy. 2011. The Precarious Migrant Status and Precarious Employment: The Paradox of International Rights for Migrant Workers. Working Paper Series. Vancouver, BC: Metropolis British Columbia.

Fudge, Judy and Fiona McPhail. 2009. The Temporary Foreign Worker Program in Canada: Low-Skilled Workers as an Extreme Form of Flexible Labour. Working Paper Series. Melbourne, AU: Centre for Employment and Labour Relations Law, University of Melbourne.

Gibbs, Holly. 2008. Social cohesion, international competitiveness, and the 'other': A connected comparison of workers' relationships in Canada and Mexico. Pp. 38-62 in Robert O'Brien, ed., Solidarity First: Canadian Workers and Social Cohesion. Vancouver, BC: UBC Press.

Green, Andy, Germ Janmaat, and Christine Han. 2009. Regimes of Social Cohesion. LLAKES Research Paper. London: Centre for Learning and Life Chances in Knowledge Economies and Societies. http://www.ioe.ac.uk/ about/documents/Regimes_of_Social_Cohesion_\%28PDF_1\%29.pdf.

de Guerre, Katherine. 2009. Temporary Foreign Workers in Alberta's Oil Sector. Working Paper. Sussex, UK: Sussex Centre for Migration Research, University of Sussex.

Gunderson, Morley. 2009. Review of Canadian and International Literature on Apprenticeships. Ottawa: Human Resources and Skills Development Canada.

Haan, Michael. 2010. Measuring Alberta's shadow population. Presented at the Unwrap Research Conference, October, Fort McMurray. http://www.uofaweb.ualberta.ca/crsc/pdfs/Unwrap___Measuring_Alberta\%27s_Shadow_Population.pdf.

Hennebry, Jenna. 2010. Who has their eye on the ball? 'Jurisdictional futbol' and Canada's Temporary Foreign Worker Program. Policy Options (July/ August):62-67.

Hillery, George A. 1955. Definitions of community: Areas of agreement. Rural Sociology 20:111-123.

Human Resources and Skills Development Canada (HRSDC). 2012. Accelerated Labour Market Opinion Fact Sheet. Ottawa. http://www.hrsdc.gc.ca/ eng/workplaceskills/foreign_workers/almo/factsheet.shtml.

Johnson, Nick. 2007. Building an integrated society. Pp. 24-33 in Margaret Wetherell, Michelynn Lafleche, and Robert Berkeley, eds., Identity, Ethnic Diversity and Community Cohesion. London, Thousand Oaks, CA: Sage.

Leach, Belinda and Charlotte Yates. 2008. Gendering the concept of social cohesion through an understanding of women and work. Pp. 21-37 in Robert O'Brien, ed., Solidarity First: Canadian Workers and Social Cohesion. Vancouver, BC: UBC Press. 
Martin, Philip. 2003. Managing Labor Migration: Temporary Worker Programs for the 21st Century. Geneva: International Institute for Labour Studies. http://www.ilo.org/public/english/bureau/inst/download/migration3.pdf. 2010. A need for migrant labour? UK-US comparisons. In Martin Ruhs and Bridget Anderson, eds., Who Needs Migrant Workers? Labour Shortages, Immigration, and Public Policy. New York: Oxford University Press.

McGhee, Derek. 2003. Moving to 'our' common ground - a critical examination of community cohesion discourse in twenty-first century Britain. The Sociological Review 51(3):376-404. doi:10.1111/1467-954X.00426.

Nakache, Delphine and Paula J. Kinoshita. 2010. The Canadian Temporary Foreign Worker Program: Do Short-Term Economic Needs Prevail over Human Rights Concerns? Montreal: Institute for Research on Public Policy.

Nichols Applied Management. 2007. Report on Mobile Workers in the Wood Buffalo Region of Alberta. Edmonton: Athabasca Regional Issues Working Group.

O'Brien, Robert. 2008. Introduction: Canadian workers and social cohesion. Pp. 1-20 in Robert O'Brien, ed., Solidarity First: Canadian Workers and Social Cohesion. Vancouver, BC: UBC Press.

Oil Sands Ministerial Strategy Committee. 2006. Investing in Our Future: Responding to the Rapid Growth of Oil Sands Development. Edmonton: Government of Alberta. http://alberta.ca/home/395.cfm?

Pastor, Manuel and Susan Alva. 2004. Guest workers and the new transnationalism: Possibilities and realities in an age of repression. Social Justice 31(1-2):92-112.

Plant, R. 1978. Community: concept, conception, and ideology. Politics \& Society 8(1):79-107. doi:10.1177/003232927800800103.

Prasil, Sandrine. 2005. Registered Apprentices: The Class of 1992, a Decade Later. Research Paper. Ottawa: Statistics Canada. http://www.statcan. gc.ca/pub/81-595-m/81-595-m2005035-eng.pdf.

Putnam, Robert D. 1993. The prosperous community: Social capital and public life. American Prospect 4(13):35-42. 2000. Bowling Alone. New York: Simon \& Schuster.

2007. E pluribus unum: Diversity and community in the twenty-first century. The 2006 Johan Skytte Prize Lecture. Scandinavian Political Studies 30(2):137-174. doi:10.1111/j.1467-9477.2007.00176.x.

Reitz, J. and R. Banerjee. 2007. Racial inequality, social cohesion and policy issues in Canada. Pp. 489-546 in Keith Banting, Thomas Courchene, and Leslie Seidle, eds., Belonging? Diversity, Recognition and Shared Citizenship in Canada. Montreal: Institute for Research on Public Policy.

Robinson, David. 2005. The search for community cohesion: Key themes and dominant concepts of the public policy agenda. Urban Studies 42(8):1411-1427. doi:10.1080/00420980500150755. 
Rogaly, Ben and Becky Tayler. 2007. Welcome to 'Monkey Island': Identity and community in three Norwich estates. Pp. 61-74 in Margaret Wetherell, Michelynn Lafleche, and Robert Berkeley, eds., Identity, Ethnic Diversity and Community Cohesion. London;Thousand Oaks, CA: Sage.

Ruhs, Martin. 2002. Temporary Foreign Workers Programmes: Policies, Adverse Consequences, and the Need to Make Them Work. Working Paper. San Diego: Center for Comparative Immigration Studies, University of California.

Sharma, Nandita. 2001. On being not Canadian: The social organization of 'migrant workers' in Canada. Canadian Review of Sociology/Revue Canadienne De Sociologie 38(4):415-439.

2007. Freedom to discriminate: A national state sovereignty and temporary migrant workers in Canada. Pp. 163-183 in Gokce Yurdakul and Y. Michal Bodemann, eds., Citizenship and Immigrant Incorporation. New York: Palgrave Macmillan.

Slootman, Tim. 2007. Planning of mega-projects: Influence of execution planning on project performance. Enschende, NL: University of Twente. http://essay.utwente.nl/725/1/scriptie Slootman.pdf.

Tam, Henry. 2007. The case for progressive solidarity. Pp. 17-23 in Margaret Wetherell, Michelynn Lafleche, and Robert Berkeley, eds,. Identity, Ethnic Diversity and Community Cohesion. London;Thousand Oaks, CA: Sage.

Toye, Michael. 2007. Social Cohesion: The Canadian Urban Context. Ottawa: Parliamentary Information and Research Service.

Vergunst, Petra J.B. 2009. Whose socialisation? Exploring the social interaction between migrants and communities-of-place in rural areas. Population, Space and Place 15(3):253-266. doi:10.1002/psp.517.

Vertovec, Steven. 2009. Transnationalism. London: Routledge.

Wetherell, Margaret. 2007. Introduction. Pp. 1-14 in Margaret Wetherell, Michelynn Lafleche, and Robert Berkeley, eds., Identity, Ethnic Diversity and Community Cohesion. London;Thousand Oaks, CA: Sage.

Wetherell, Margaret, Michelynn Lafleche, and Robert Berkeley, eds. 2007. Identity, Ethnic Diversity and Community Cohesion. London;Thousand Oaks, CA: Sage.

Winchie, Diana B. and David W. Carment. 1989. Migration and motivation: The migrant's perspective. International Migration Review 23(1):96-104.

Wong, Lloyd L. 1984. Canada's guestworkers: Some comparisons of temporary workers in Europe and North America. International Migration Review 18(1):85-98.

Worley, Claire. 2005. 'It's not about race. It's about the community': New labour and 'community cohesion'. Critical Social Policy 25(4):483-496. doi: $10.1177 / 0261018305057026$. 
Young, Iris Marion. 1986. The ideal of community and the politics of difference. Social Theory and Practice 12:1-26.

Jason Foster is Academic Coordinator, Industrial Relations at Athabasca University. His research interests include migrant workers, union representation of vulnerable workers, and strategies for union renewal in the 21st century. Recent publications include "Making Temporary Permanent: The Silent Transformation of the Temporary Foreign Worker Program" in Just Labour: A Canadian Journal of Work and Society (2012), and (with Bob Barnetson) "Justice for Janitors in Alberta: The impact of temporary foreign workers on an organizing campaign" in Journal of Workplace Rights (2012).

Alison Taylor is a professor in the Department of Educational Policy Studies at the University of Alberta. Her research interests include learning and the workplace, and school-to-work transitions. She is co-editor (with Peter Sawchuk) of 'Challenging Transitions in Learning and Work' (Sense, 2010) and published an article on temporary foreign workers in nursing (with Jason Foster and Carolina Cambre) entitled 'Training 'expendable' workers: Temporary foreign workers in nursing' in Globalisation, Societies and Education. 